\title{
Triploids and Haploid Progenies Derived from Small Seeds of 'Banpeiyu', a Pummelo, Crossed with 'Ruby Red' Grapefruit
}

\author{
Pichit Toolapong*, Haruki Komatsu and Masao Iwamasa \\ School of Agriculture, Kyushu Tokai University, Choyo, Aso, Kumamoto 869-14
}

\begin{abstract}
Summary
In order to establish a triploid grapefruit-like cultivar adaptable to the citrus area of Japan, 'Banpeiyu' (Citrus grandis Osbek) was crossed with 'Ruby Red' grapefruit (C. paradisi Macf.). Out of 2,049 seeds, 82 were selected as small seeds. Among the seedlings obtained from the small seeds, one haploid, 18 diploids, and 51 triploids segregated. The haploid seedling has a dwarf growth habit with a roseate leaf type. When grafted onto trifoliate orange (Poncirus trifoliata Raf.) rootstock, however, it grew normally. The triploids grew poorly immediately after germination, but after one year they grew as vigorously and as well as the diploid seedlings derived from the normal large seeds.
\end{abstract}

\section{Introduction}

Seedlessness is a trait that is essential for any new citrus cultivar intended for the fresh fruit market. The most important fresh citrus fruit cultivars in the world, such as the naval oranges, satsuma mandarins, Clementine mandarins, and some cultivars of grapefruits, are virtually seedless. Triploid plants generally produce seedless fruits. 'Tahiti' lime is the only triploid citrus cultivar which originated spontaneously, producing seedless fruits (Krug, 1943).

Soost and Cameron (1980, 1985) produced promising new triploid cultivars, 'Oroblanco' and 'Melogold' from a cross between a diploid acidless pummelo and a tetraploid grapefruit. 'Oroblanco' fruits are imported to Japan from California, and from Israel under the name of 'Sweetie' because they are in high favour with consumers.

Unexpected triploids have occurred among the progenies of diploid citrus cultivars open-pollinated or crossed by diploids (Lapin, 1937 ; Frost, 1943 ; Iwamasa, 1966). Esen and Soost (1971) found that small seeds from crosses of $2 \times \times 2 \times$ pro-

Received 11 August 1995. Accepted 22 December 1995.

This work was supported in part by a grant from the Tokai University General Research Organization.

* Present address: Faculty of Agriculture, Maejo Univeristy, Chiang Mai, Thailand 50290 duced unexpected triploids when monoembryonic cultivars were used as seed parents. Esen et al. (1979) pointed out that triploid seeds resulted from unreduced diploid female gametes fertilized with haploid male gametes. The diploid female gamete attributed to the omission of second meiotic division or endoduplication in the functional megaspores. The reduction of seed size in the triploid seeds was due to the precocious termination of development in the pentaploid endosperm, related to $3: 5$ ploidy ratio between embryo and endosperm (Esen and Soost, 1971, 1973).

Frequency of the small triploid seeds is attrib. uted to the seed parent. When a diploid cultivar with a high frequency for small triploid seeds is used as seed parent, we can produce many triploid plants from the small seeds of crosses between diploid cultivars without tetraploidy.

Because of the comparatively short summers and prolonged cold season in Japan, grapefruit can not be successfully grown, as the species need high temperature for fruit development, growth and ripening. Citrus growers seek new grapefruit cultivars adapted to the environmental conditions of Japan.

In preliminary experiments using open-pollinated seeds (Toolapong, 1994), 'Banpeiyu', a pummelo cultivar, yielded the highest number of the small triploid seeds among pummelos. This pum. 
melo cultivar introduced from Thailand is so welladapted to the climatic conditions of Japan, producing large $(2 \mathrm{Kg})$, attractive, good quality fruit.

In this paper, we describe how triploid hybrid seedlings were attained from small seeds of 'Banpeiyu' pummelo $\times$ 'Ruby Red' grapefruit. Some of the superior seedless selections may bring about a new citrus industry in Japan.

\section{Materials and Methods}

'Banpeiyu' pummelo was pollinated with 'Ruby Red' grapefruit at the Fruit Tree Research Institute, Kumamoto Prefectural Agricultural Research Center, Matsubase, Kumamoto, in May, 1993. 'Ruby Red' grapefruit pollen collected at Citrus Experimental Orchard, Faculty of Agriculture, Saga University was applied to emasculated flowers of 'Banpeiyu' and covered with paraffin paper bags. The pollinated fruits were harvested at maturity between November and early January and their seeds were extracted and classified into two categories: normal, large and small. After the small seeds were weighed and their seed coats removed, they were placed on double layers of moistened filter paper and kept at $25{ }^{\circ} \mathrm{C}$ for about seven days. After germination, the seeds were transplanted into vermiculite in boxes and transferred to a greenhouse.

Chromosomes were counted in root-tip squashes according to Oiyama's method (1981) by pretreat- ing them with $0.002 \mathrm{M} 8$-hydroxyquinoline at 15 ${ }^{\circ} \mathrm{C}$ for 18 hours. The tips were washed $2-3$ times in distilled water, fixed in 1:3 acetic alcohol solution for 24 hours, hydrolyzed and stained in $1 \%$ lacto-propionic orcein for about three hours, and finally squashed.

\section{Results}

From 100 flowers of 'Banpeiyu' pollinated with 'Ruby Red' grapefruit 42 fruits set (Table 1). Out

Table 1. Haploid, diploid and triploid progenies derived from the small seeds of 'Banpeiyu' pummelo x 'Ruby Red' grpefruit.

\begin{tabular}{|c|c|c|c|c|c|c|c|}
\hline \multirow{3}{*}{$\begin{array}{l}\text { No. of } \\
\text { flowers } \\
\text { pollinated }\end{array}$} & \multirow{3}{*}{$\begin{array}{c}\text { No. of } \\
\text { set } \\
\text { fruits }\end{array}$} & \multirow{3}{*}{$\begin{array}{l}\text { No. of } \\
\text { total } \\
\text { seeds }\end{array}$} & \multirow{3}{*}{$\begin{array}{l}\text { No. of } \\
\text { small } \\
\text { seeds }\end{array}$} & \multirow{3}{*}{$\begin{array}{l}\text { No. of } \\
\text { seedlings } \\
\text { examined }\end{array}$} & \multirow{2}{*}{\multicolumn{3}{|c|}{$\frac{\text { No. of seedlings }}{\text { Ploidy }}$}} \\
\hline & & & & & & & \\
\hline & & & & & $\mathrm{x}$ & $2 x$ & $3 x$ \\
\hline 100 & 42 & 2,049 & 82 & 70 & 1 & 18 & 51 \\
\hline
\end{tabular}

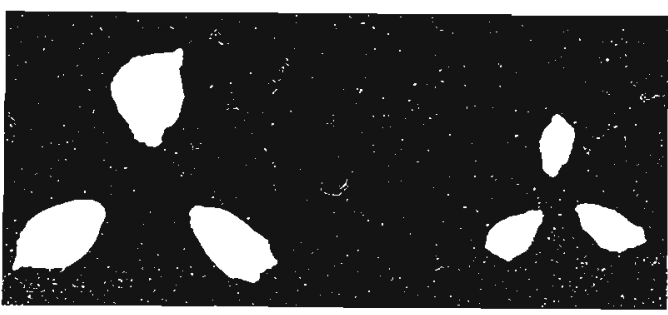

Fig. 1. Normal (left) and small (right) seeds from 'Banpeiyu' pummelox 'Ruby Red' grapefruit.

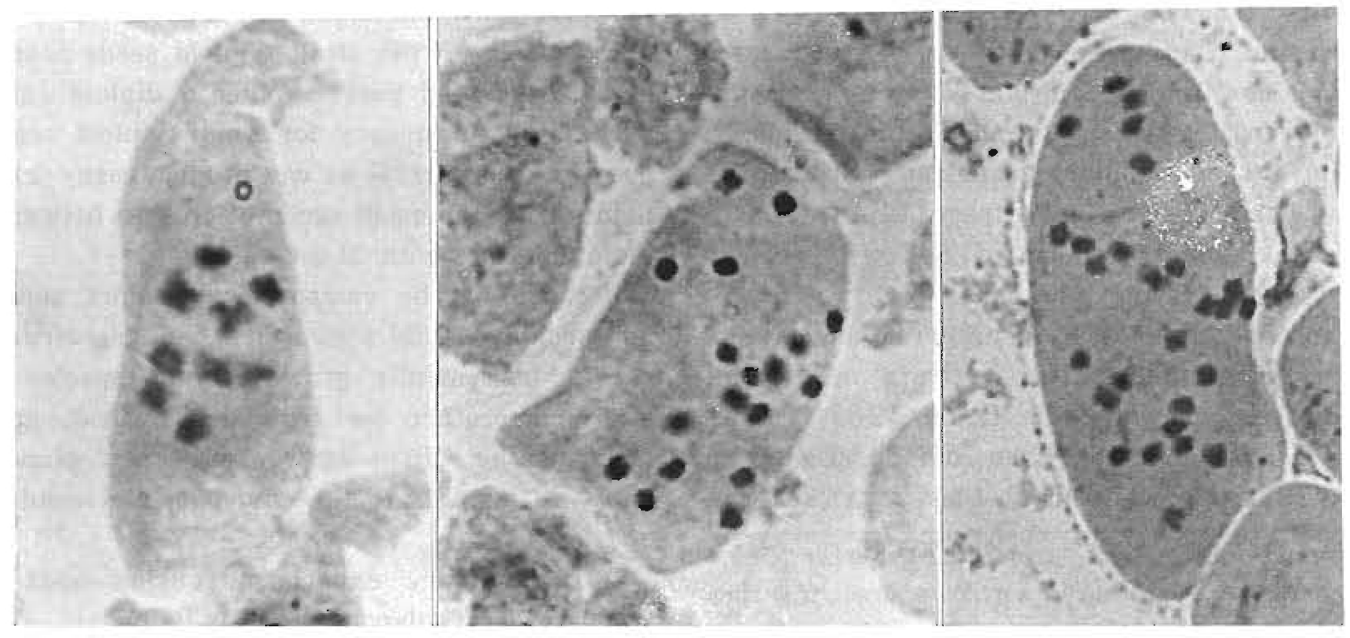

Fig. 2. Chromosomes of root-tip cells. Haploid (left). diploid (center) and triploid (right) in seedlings of 'Banpeiyu' pummelox'Ruby Red' grapefruit $(\times 2,000)$. 
of 2,049 seeds extracted from the mature fruits, 82 were selected as small seeds (Fig. 1). From this population, 70 seedlings, upon examination, yielded one haploid, 18 diploids, and 51 triploids were determined (Table 1, Fig. 2). The average weights of normal and small seeds were $470 \mathrm{mg}$ and $141 \mathrm{mg}$, respectively. The haploid came from a $170 \mathrm{mg}$ seed (Table 2). Among the small seeds, the border line between diploid and triploid seeds was about $200 \mathrm{mg}$. Seven seeds weighing more than $200 \mathrm{mg}$ were diploid ; likewise 11 small seeds weighing less than $200 \mathrm{mg}$ produced diploid seedlings. All triploid seeds weighed less than 200 mg (Fig. 3).

The triploid seedlings grew poorly in the early

Table 2. Range of seed weights of small seed of diploids and triploids.

\begin{tabular}{|c|c|c|c|c|c|}
\hline \multirow{3}{*}{ Cross combination } & \multirow{2}{*}{$\begin{array}{c}\text { Av. seed wt. } \\
\text { (mg) } \\
\end{array}$} & \multirow{2}{*}{\multicolumn{2}{|c|}{$\frac{\begin{array}{c}\text { Av. small seed wt. } \\
\text { (mg) }\end{array}}{\text { Ploidy }}$}} & \multirow{2}{*}{\multicolumn{2}{|c|}{$\begin{array}{l}\text { Ranges of small } \\
-\frac{\text { seeds wt. (mg) }}{\text { Ploidy }}\end{array}$}} \\
\hline & & & & & \\
\hline & Large Small & $2 \mathrm{x}$ & $3 x$ & $2 \mathrm{x}$ & $3 x$ \\
\hline Banpeiyu x Ruby Red & 141 & $170 \quad 228$ & 129 & $280-146$ & $190-70$ \\
\hline
\end{tabular}

stages after germination compared to diploid ones from normal-sized seeds (Fig. 4). One year after germination, however, they grew vigorously, similar to diploid ones.

The haploid seedling was very dwarfish with roseate leaf type. When its shoot tip was micrografted onto a young seedling of trifoliate orange, the scion grew very well (Fig. 5).

\section{Discussion}

Of the 2,049 seeds obtained from 'Banpeiyu' pummelo $\times$ 'Ruby Red' grapefruit, about $4 \%$ were small and visually distinguishable from normal ones.

Out of 70 seedlings examined, 51 (72.86\%) were triploid. Esen and Soost (1971) found that almost all small seeds were triploid when diploid 'Sukega' orangelo, 'Temple' tangor and 'Clementine' mandarin were used as seed parents. In this trial when 'Banpeiyu' was the seed parent, about $27 \%$ of small seeds produced diploid seed. lings. These fully developed diploid seeds could not be differentiated from the triploid small seeds. The difference between our results and those of Esen and Soost may be due to cultivars differences.

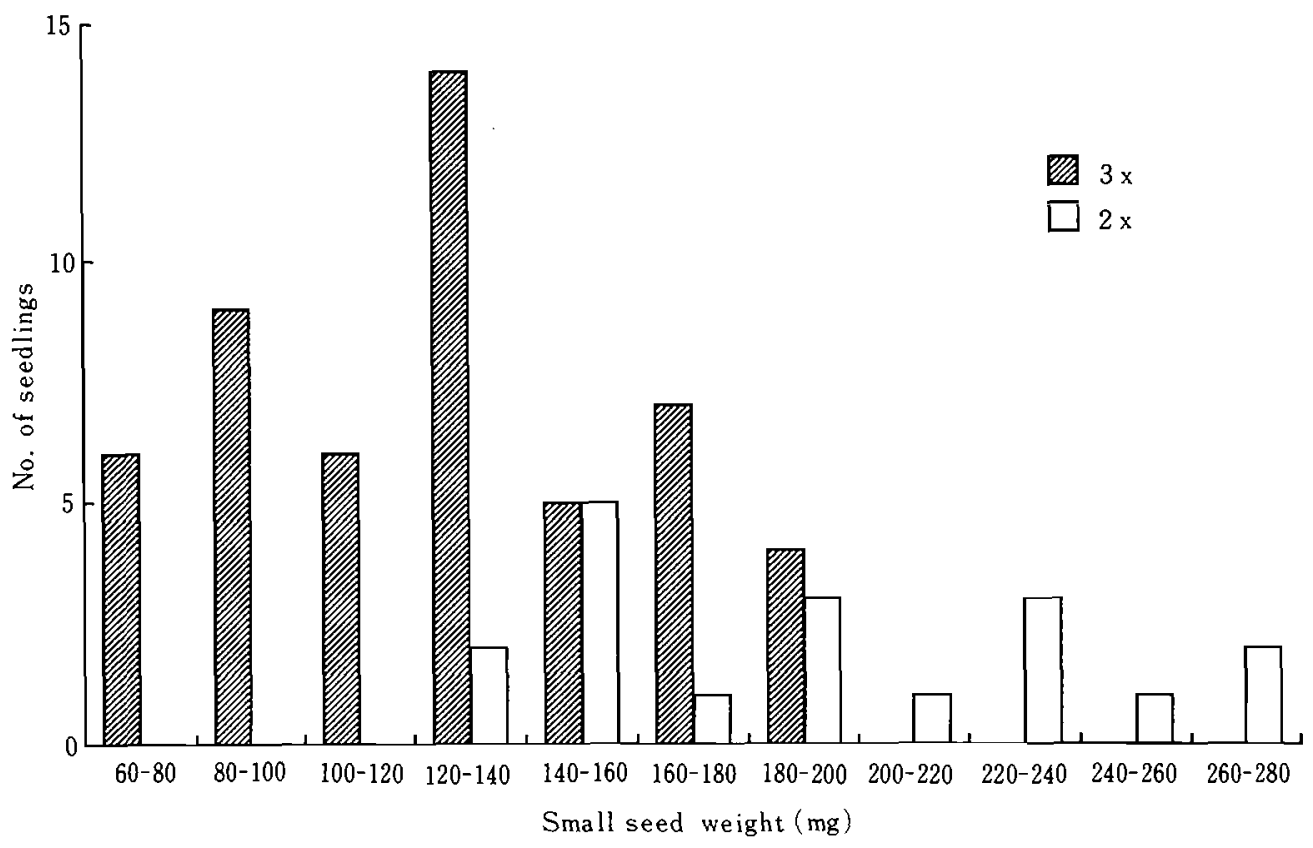

Fig. 3. Distribution frequency of $2 x$ and $3 x$ seed weights from obtained 'Banpeiyu' pummelo $\times$ 'Ruby Red' grapefruit. 


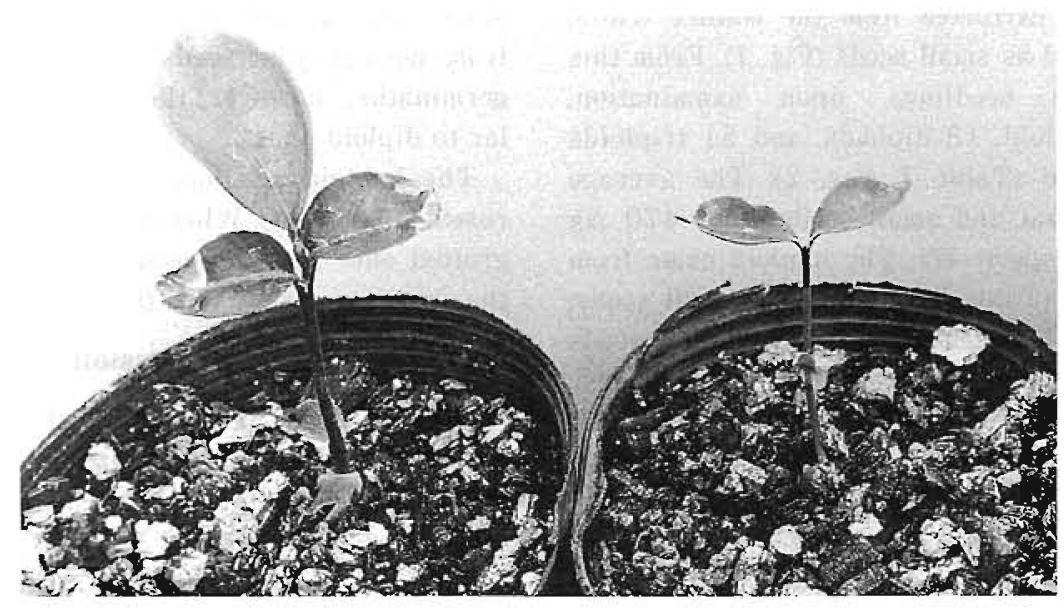

Fig. 4. Diploid (left) and triploid (right) seedlings from 'Banpeiyu' pummelo $\times$ 'Ruby Red' grapefruit, three months after germination.

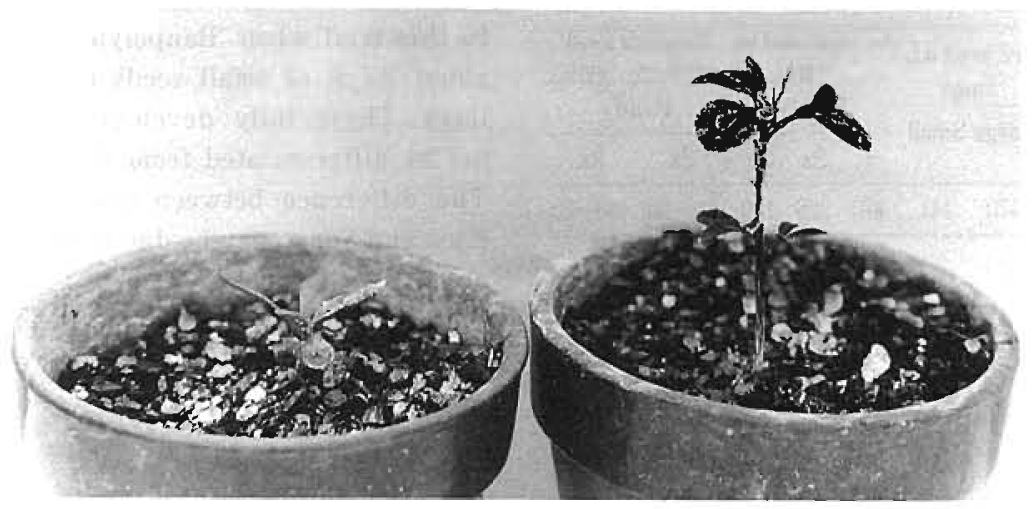

Fig. 5. Haploid seedling from 'Banpeiyu' pummelox 'Ruby Red' grapefruit. Original plant (left) and grafted plant (right) on trifoliate orange.

When 'Banpeiyu' was used as a seed parent, 83 $\%$ of the small seeds weighing less than $200 \mathrm{mg}$ were determined to be triploids by counting the root tip chromosomes. The selection of triploids from small seeds of 'Banpeiyu' provides a new approach for breeding triploid cultivars, especially for establishing a seedless grapefruit cultivar adaptable to the climatic conditions in citrus areas of Japan. These triploid plants will be tested in a future breeding program.

A haploid was obtained from small seed in this trial. In citrus, Hidaka et al. (1979) and Chen et al. (1980) obtained haploids by anther culture technique. Hidaka's haploid of trifoliate orange died at a young stage. Karasawa (1971) produced haploids from seed irradiated by X-ray.

Oiyama and Kobayashi (1993) obtained haploid seedlings from 'Clementine' and 'Lee', using the pollen from a triploid progeny of $2 \mathrm{x}$ 'Naruto' (C. medioglobosa Hort. ex Tanaka) $\times 4 \mathrm{x}$ 'Funadoko' (C. funadoko Hort. ex Tanaka). The haploid plants are still growing after being grafted on trifoliate orange rootstock. The isozyme analysis revealed that the haploids originated from the eggs of the maternal plants. Esen and Soost (1971) observed a haploid embryo in a immature seed of 'Clementine' x'Pearl'.

Our haploid. is the first progeny obtained from a 
cross between two diploid citrus cultivars. We assume that the haploid originated from an unfertilized egg of the maternal 'Banpeiyu' accompanied by a normal $3 \mathrm{x}$ endosperm which provided the nutrients and hormones for the egg to develop into an embryo. The haploid seedling has dwarf growth habit and roseate leaf, similar to haploids obtained by Oiyama and Kobayashi (1993). Both their haploids and ours are growing well after being grafted onto young seedlings of trifoliate orange. Haploid plants are of great value in breeding and genetic studies because homodiploid plants derived from doubling of the chromosomes represent the genotype of a gametophyte from the maternal 'Banpeiyu'. The homozygous plants produce gametes, with the same genetic constitution, which play an interesting role in citrus breeding. Our haploid plant will be used in future genetic and breeding studies.

\section{Acknowledgements}

The authors wish to thank Mr. Akira Isobe, Fruit Tree Research Institute, Kumamoto Prefectural Agricultural Research Center and Mr. Seiji Yamaguchi, Faculty of Agriculture, Saga University for providing the experimental materials. The authors are grateful to Dr. J. W. Cameron, Emeritus Professor of University of California, Riverside, for his helpful suggestions.

\section{Literature Cited}

Chen, Z., M. W ang and H. Liao. 1980. The induction of citrus pollen plants in artificial media. Acta Genet. Sinica $7: 189-191$.

Esen, A. and R. K. Soost. 1971. Unexpected triploids in Citrus: The origin, identification, and possible use. J. Hered, $62:$ 329-333.

Esen, A. and R. K. Soost. 1973. Precocious development and germination of spontaneous triploid seeds in Citrus. J. Hered. $64:$ 147-154.

Esen, A., R. K. Soost and G. Geraci. 1979. Genetic evidence for the origin of diploid megagametophytes in Citrus. J. Wash. Acad. Sci. $15: 1-3$.

Frost, H. B. 1943. Genetics and breeding. p. 817-913. In: L. D. Batchelor and H. J. Webber (eds.). The Citrus Industry. Vol. I. University of California Press, Berkeley and Los Angeles.

Hidaka, T., Y. Yamada and T. Shichijo. 1979. In vitro differentiation of haploid plants by anther culture in Poncirus trifoliata (L) Raf. Japan. J. Breed. 29 : 248-254.

Iwamasa, M. 1966. Studies on the sterility in genus Citrus with special reference to the seedlessness. Bull. Hort. Res. Sta. Japan, Ser. B. No. $6: 1-81$.

Karasawa, K. 1971. On the occurrence of haploid seedlings in Citrus natsudaidai Hayata. Sakushingakuin Junior College for Women Bull., Biological Institute, Utsunomiya, Tochigi, $1: 1-2$.

Krug, C. A. 1943. Chromosome numbers in the subfamily Aurantioideae with special reference to the genus Citnus. Bot. Gaz. 104: 602-611.

Lapin, W. K. 1937. Investigations on polyploidy in Cit rus. U.S.S.R. All-Union Sci. Res. Inst. Humid. Subtrop. Work 1:1-68. (In Russian with English summary).

Oiyama, I. 1981. A technique for chromosome observation in root tip cells of citrus. Fruit Tree Res. Sta. Bull., D $3: 1-7$. (In Japanese with English summary).

Oiyama, I. and S. Kobayashi. 1993. Haploids obtained from diploid $\times$ triploid crosses of Citrus. J. Japan. Soc. Hort. Sci. $62: 89-93$.

Soost, R. K. and J. W. Cameron. 1980. 'Oroblanco', a triploid pummelo-grapefruit hybrid. HortScience $15: 667-669$.

Soost, R. K. and J. W. Cameron. 1985. 'Melogold', a triploid pummelo-grapefruit hybrid. HortScience 20 : $1134-1135$.

Toolapong, P. 1994. Triploids and aneuploids in citrus fruits. Ph. D. Dissertation. Kyushu Tokai Univ. Aso, Kumamoto, Japan. 
‘ルビーレッド’グレープフルーツを交配した“晚白柚”の小粒種子より生じた半数体と三倍体

Pichit Toolapong・小松春喜・岩政正男

\section{九州東海大学農学部 869-14 阿蘇郡長陽村河陽}

\section{摘 要}

我が国で栽培可能なグレープフルーツに代わるカン キツ新品種を䏍成する目的で，“晚白柚”にルビーレ ッドグレープフルーツを交配し，その小粒種子より 三倍体作出を試みた。 2,049 粒の完全種子が得られ， そのうち小粒種子は 82 粒であった。これより㕕成し た70 個体の実生が染色体観察に供せられ，1個体の
半数体, 18 個体の二倍体, 51 個体の三倍体が観察さ れた，半数体はロゼット状を呈し極めてわい小であっ たが，カラタチ台に接ぎ木すると正常な生育を示した。 三倍体も発芽当初はわい小であったが，1 年後には通 常の二倍体実生と変わらない大きさに育った。 